medRxiv preprint doi: https://doi.org/10.1101/2021.01.05.20249061; this version posted January 6, 2021. The copyright holder for this preprint (which was not certified by peer review) is the author/funder, who has granted medRxiv a license to display the preprint in perpetuity.

It is made available under a CC-BY-NC-ND 4.0 International license.

\title{
THE INTESTINAL AND ORAL MICROBIOMES ARE ROBUST PREDICTORS OF COVID-19 SEVERITY THE MAIN PREDICTOR OF COVID-19-RELATED FATALITY
}

\section{Doyle V. Ward ¥}

Department of Microbiology and Physiological Systems and Program of Microbiome Dynamics. University of Massachusetts Medical School

\section{Shakti Bhattarai ‡}

Department of Microbiology and Physiological Systems and Program of Microbiome Dynamics. University of Massachusetts Medical School

\section{Mayra Rojas-Correa}

Department of Microbiology and Physiological Systems and Program of Microbiome Dynamics. University of Massachusetts Medical School

Ayan Purkayastha

University of Massachusetts Medical School

Devon Holler

Department of Microbiology and Physiological Systems and Program of Microbiome Dynamics. University of Massachusetts Medical School

Ming Da Qu

Division of Infectious Diseases and Immunology. University of Massachusetts Memorial Healthcare Center

William G. Mitchell

Departments of Internal Medicine/Pediatrics. University of Massachusetts Medical School 
medRxiv preprint doi: https://doi.org/10.1101/2021.01.05.20249061; this version posted January 6, 2021. The copyright holder for this preprint (which was not certified by peer review) is the author/funder, who has granted medRxiv a license to display the preprint in perpetuity. It is made available under a CC-BY-NC-ND 4.0 International license.

Jason Yang

Internal Medicine, Department of Medicine, University of Massachusetts Medical School

Samuel Fountain

University of Massachusetts Medical School

Abigail Zeamer

Department of Microbiology and Physiological Systems and Program of Microbiome Dynamics. University of Massachusetts Medical School

\section{Catherine Forconi}

Department of Medicine. Division of Infectious Diseases and Immunology. University of Massachusetts Medical School

Gavin Fujimori

Department of Medicine. Division of Infectious Diseases and Immunology. University of Massachusetts Medical School

\section{Boaz Odwar}

Department of Medicine. Division of Infectious Diseases and Immunology. University of Massachusetts Medical School

\section{Caitlin Cawley}

Department of Microbiology and Physiological Systems and Program of Microbiome Dynamics. University of Massachusetts Medical School 
medRxiv preprint doi: https://doi.org/10.1101/2021.01.05.20249061; this version posted January 6, 2021. The copyright holder for this preprint (which was not certified by peer review) is the author/funder, who has granted medRxiv a license to display the preprint in perpetuity. It is made available under a CC-BY-NC-ND 4.0 International license.

\section{Beth A. McCormick}

Department of Microbiology and Physiological Systems and Program of Microbiome Dynamics. University of Massachusetts Medical School

\section{Ann Moormann}

Department of Medicine. Division of Infectious Diseases and Immunology. University of Massachusetts Medical School

Mireya Wessolossky

Department of Medicine. Division of Infectious Diseases and Immunology. University of Massachusetts Medical School

\section{Vanni Bucci}

Department of Microbiology and Physiological Systems and Program of Microbiome Dynamics. University of Massachusetts Medical School

\section{Ana Maldonado-Contreras}

Department of Microbiology and Physiological Systems and Program of Microbiome Dynamics. University of Massachusetts Medical School

$\$$ These authors contributed equally

Corresponding authors in bold

\section{Authors Conflict of Interest:}

Beth A. McCormick (BMC) is a Scientific Founder of the start-up company Bacainn Therapeutics. The remaining authors do not have any conflict of interest to disclose. 
medRxiv preprint doi: https://doi.org/10.1101/2021.01.05.20249061; this version posted January 6, 2021. The copyright holder for this preprint (which was not certified by peer review) is the author/funder, who has granted medRxiv a license to display the preprint in perpetuity.

It is made available under a CC-BY-NC-ND 4.0 International license .

\section{ABSTRACT}

The reason for the striking differences in clinical outcomes of SARS-CoV-2 infected patients is still poorly understood. While most recover, a subset of people become critically ill and succumb to the disease.

Thus, identification of biomarkers that can predict the clinical outcomes of COVID-19 disease is key to help prioritize patients needing urgent treatment. Given that an unbalanced gut microbiome is a reflection of poor health, we aim to identify indicator species that could predict COVID-19 disease clinical outcomes. Here, for the first time and with the largest COVID-19 patient cohort reported for microbiome studies, we demonstrated that the intestinal and oral microbiome make-up predicts respectively with $92 \%$ and $84 \%$ accuracy (Area Under the Curve or AUC) severe COVID-19 respiratory symptoms that lead to death. The accuracy of the microbiome prediction of COVID-19 severity was found to be far superior to that from training similar models using information from comorbidities often adopted to triage patients in the clinic (77\% AUC). Additionally, by combining symptoms, comorbidities, and the intestinal microbiota the model reached the highest AUC at $96 \%$. Remarkably the model training on the stool microbiome found enrichment of Enterococcus faecalis, a known pathobiont, as the top predictor of COVID-19 disease severity. Enterococcus faecalis is already easily cultivable in clinical laboratories, as such we urge the medical community to include this bacterium as a robust predictor of COVID-19 severity when assessing risk stratification of patients in the clinic. 
medRxiv preprint doi: https://doi.org/10.1101/2021.01.05.20249061; this version posted January 6, 2021. The copyright holder for this preprint (which was not certified by peer review) is the author/funder, who has granted medRxiv a license to display the preprint in perpetuity.

It is made available under a CC-BY-NC-ND 4.0 International license .

\section{INTRODUCTION}

An estimated $20 \%$ of individuals infected with SARS-CoV-2 require hospitalization, with a subset of patients requiring intensive care. Why some individuals become deathly ill while others don't is still unknown. Despite the rollout of vaccination campaigns against SARS-CoV-2, the threat of this infection is ongoing. As hospitals worldwide are challenged with episodic resurgences of patients with COVID-19 disease, there is an urgent need for pragmatic yet accurate risk stratification biomarkers that could predict which patients are high risk for progression to severe disease and death. Precise risk stratification protocols can help justify resource allocation, if faced with limitations, and guide staffing decisions for efficient patient management.

In an effort to develop such a protocol, the International Severe Acute Respiratory and emerging Infections Consortium (ISARIC) World Health Organization (WHO) described in September 2020, a comprehensive risk stratification tool for SARS-CoV-2 hospitalized patients: 4C Mortality score ${ }^{1}$. The 4C Mortality Score included eight variables: age, sex, number of comorbidities, respiratory rate, peripheral oxygen saturation, level of consciousness, urea level, and $\mathrm{C}$ reactive protein. However, this scoring system has only $79 \%$ of accuracy ${ }^{1}$. That is, out of 10 COVID-19 patients, the 4C Mortality Score will fail to identify 3 patients with high risk of fatality. Thus, a more precise method is critically needed to forecast hospital capacity during this pandemic. It has been established that patients with SARS-Cov-2 infection exhibit gut microbiome dysbiosis when compared to healthy individuals (reviewed ${ }^{2}$ ). More recently, a total of 23 bacterial taxa was found to be strongly associated with disease severity among hospitalized COVID-19 patients ${ }^{3}$.

Here, we capitalized on a robust and validated predictive analytic and computational framework developed by us ${ }^{4-6}$ to define and model complex interactions between the microbiota, clinical variables, and disease severity. Hence, we discovered oral and intestinal bacteria species that can be used to accurately predict fatality of COVID-19 hospitalized patients. 
medRxiv preprint doi: https://doi.org/10.1101/2021.01.05.20249061; this version posted January 6, 2021. The copyright holder for this preprint (which was not certified by peer review) is the author/funder, who has granted medRxiv a license to display the preprint in perpetuity.

It is made available under a CC-BY-NC-ND 4.0 International license .

\section{RESULTS}

\section{Fatality of patients with SARS-CoV-2 infection is predicted by respiratory severe symptoms.}

We enrolled 69 SARS-CoV-2 PCR positive patients with moderate or severe symptoms. In accordance with the categorization of disease severity used in the hospital, those requiring more than $4 \mathrm{~L}$ of oxygen (at the time of sample collection) were considered patients with severe symptoms; conversely, patients needing less than $4 \mathrm{~L}$ of oxygen were categorized as having moderate symptoms. Out of 69 , we included in the analysis 63 participants with complete medical records including disease outcomes (Table 1). As seen in table 1, there were no differences between the two groups in age, body mass index (BMI), sex, race, smoking status, or antibiotic administration during hospitalization. However, we observed significant differences in the duration of the hospital stay: patients with severe symptoms had an average of $\sim 6$ more days in the hospital than patients exhibiting moderate symptoms. Additional information about COVID-19 symptoms and comorbidities included in the subsequent analyses are detailed in Supplementary Table 1.

We applied Random Forest Classification to determine which of the 68 clinical covariates (Table 1 and Supplementary Table 1) plus severity of symptoms as described above could predict COVID-19 fatality on the patient cohort recruited for this study. We used the Boruta algorithm to perform feature selection and identify all the relevant clinical covariates. We found that a combination of clinical covariates which includes disease severity was able to predict a patient succumbing to COVID-19 disease with an 89\% accuracy (Area Under the Curve- Receiving Operating Curve, AUC-ROC) on leaveone-out cross validation data (Figure 1). In fact, the modeling identified the hospital classification of disease severity at the $4 \mathrm{~L}$ of oxygen requirement cut-off as the main factor predicting a patient's fatality based on the Random Forest Classification estimated Variable Importance values ${ }^{7}$ with AUC-ROC dropping to $84 \%$ when the disease severity variable was omitted (Figure $1 A$ and $B$ ). In addition, we found that other clinical variables were also more common in patient that had poor outcomes (Figure 1C and D). 
medRxiv preprint doi: https://doi.org/10.1101/2021.01.05.20249061; this version posted January 6, 2021. The copyright holder for this preprint (which was not certified by peer review) is the author/funder, who has granted medRxiv a license to display the preprint in perpetuity. It is made available under a CC-BY-NC-ND 4.0 International license.

Together, these suggest that prediction of COVID-19 outcomes is improved when taking into account respiratory symptoms, namely requiring more than $4 \mathrm{~L}$ of oxygen, along with other clinical variables commonly used to do so.

Table 1. Characteristics of COVID-19 hospitalized patients recruited in the study from April to June 2020.

\begin{tabular}{|c|c|c|c|}
\hline & Moderate $(n=32)$ & Severe $(n=31)$ & $p$-value \\
\hline \multicolumn{4}{|l|}{ Demographics } \\
\hline Age (years) & $70.53 \pm 15.86$ & $70.58 \pm 14.08$ & $0.8^{*}$ \\
\hline $\mathrm{BMI}$ & $29.22 \pm 9.19$ & $30.58 \pm 8.82$ & $0.2^{*}$ \\
\hline Female (\%) & $16(50 \%)$ & $10(30 \%)$ & $0.2^{\dagger}$ \\
\hline \multicolumn{4}{|l|}{ Race } \\
\hline White (\%) & $24(75 \%)$ & $19(59.37 \%)$ & \multirow{4}{*}{$0.2^{\wedge}$} \\
\hline Black or African American (\%) & $4(12.50 \%)$ & $3(9.37 \%)$ & \\
\hline Hispanic or Latino (\%) & $4(12.50 \%)$ & $8(25 \%)$ & \\
\hline Asian (\%) & $0(0.00 \%)$ & $2(6.25 \%)$ & \\
\hline \multicolumn{4}{|l|}{ Smoking status } \\
\hline Current & $2(6.25 \%)$ & $4(12.50 \%)$ & \multirow{3}{*}{$0.6^{\wedge}$} \\
\hline Former & $11(34.38 \%)$ & $11(34.37 \%)$ & \\
\hline Never & $19(59.38 \%)$ & $16(50 \%)$ & \\
\hline Antibiotics treatment & $26(81.25 \%)$ & $29(90.62 \%)$ & $0.2^{\wedge}$ \\
\hline Days in the hospital & $15.5+10.39$ & $21.27 \pm 12.73$ & $0.045^{*}$ \\
\hline
\end{tabular}

*Mann Whitney, unpaired t-test

${ }^{\dagger}$ Fisher T-test

^Chi-square 
medRxiv preprint doi: https://doi.org/10.1101/2021.01.05.20249061; this version posted January 6, 2021. The copyright holder for this preprint (which was not certified by peer review) is the author/funder, who has granted medRxiv a license to display the preprint in perpetuity.

It is made available under a CC-BY-NC-ND 4.0 International license.
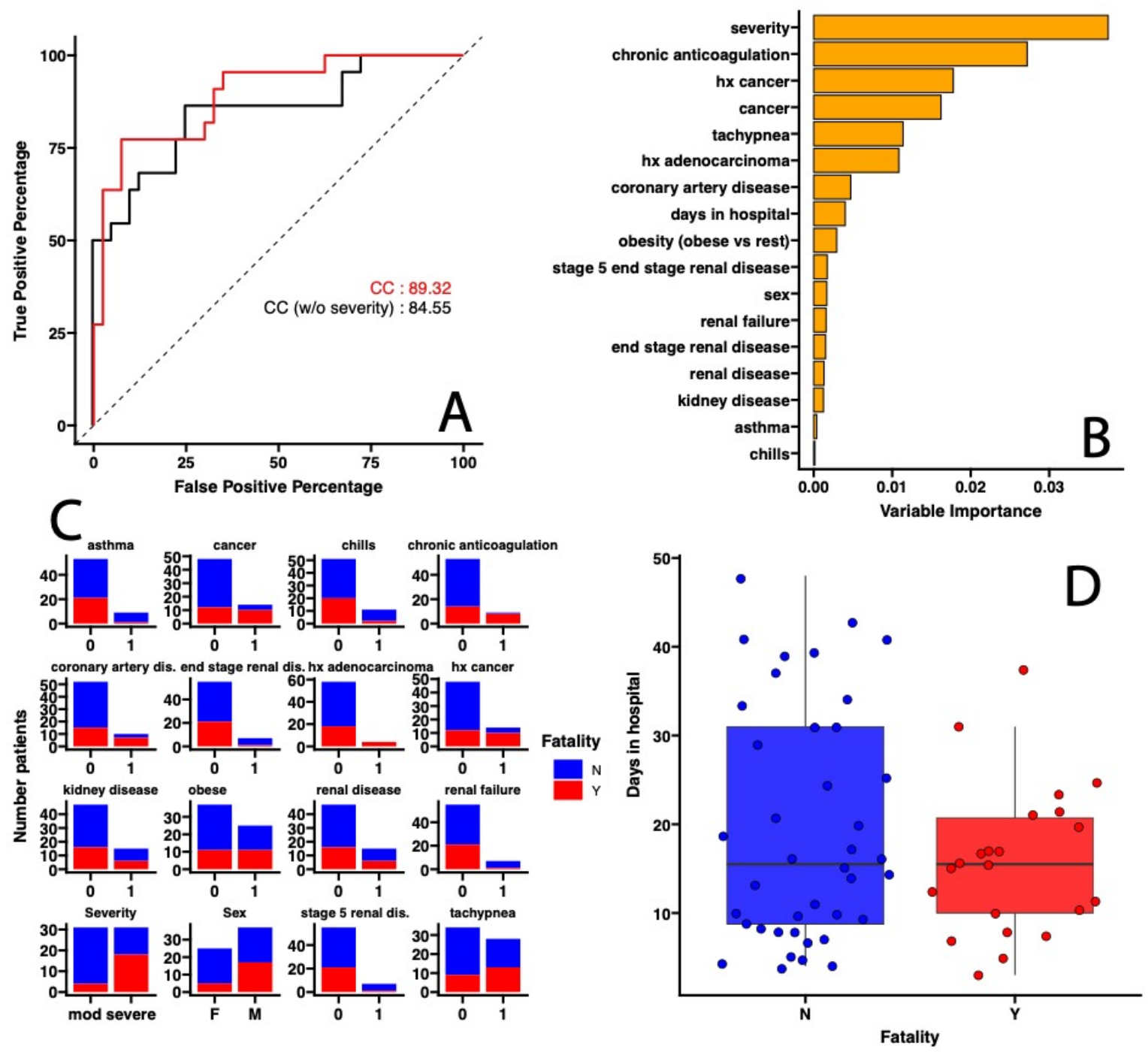

Figure 1. COVID-19 fatality is predicted by severity of respiratory symptoms and other

comorbidities commonly used to triage patients. (A) Area Under the Curve- Receiving Operating

Curve (AUC-ROC) for leave-one-out cross-validation evaluating prediction of accuracy of COVID-19

fatality. Red lines correspond to the model including all the clinical covariates (CC), black line correspond to the model including all the clinical covariates except disease severity (CC, no Severity). (B) Covariates selected by the Random Forest Classification model ranked according to their importance in classifying fatality as a disease outcome. (C) For categorical covariates (Yes=1, No=0) the number of patients out of the 63 included in the analyses within a specific category were colored by outcome (Survived, in blue; Died, in red). (D) For numerical variable, whisker plots (median, box interquartile range, $5^{\text {th }}$ and $9^{\text {th }}$ percentile for lines) are used with each solid dot corresponding to a single patient. (BH adjusted $p$ value $<0.05)$ 
medRxiv preprint doi: https://doi.org/10.1101/2021.01.05.20249061; this version posted January 6, 2021. The copyright holder for this preprint (which was not certified by peer review) is the author/funder, who has granted medRxiv a license to display the preprint in perpetuity.

It is made available under a CC-BY-NC-ND 4.0 International license .

\section{Disease severity is accurately predicted by stool or oral microbiome.}

Studies have shown that viral lung infections, including SARS-CoV-2, have a lasting effect on the gut microbiota $^{3,8-11}$. Therefore, the composition of the microbiota may contain information that is not directly measured or quantified by clinicians when triaging COVID-19 patients. We therefore decided to compare the ability in predicting COVID-19 disease severity (the main predictor of fatality) by the gastrointestinal and oral microbiome compared to commonly measured clinical covariates. We applied Random Forest Classification to predict severe vs. moderate symptoms as a function of (i) only clinical variables (Table 1 and Supplementary Table 1), (ii) intestinal microbiome composition, (iii) oral microbiome composition, (iv) clinical variables and intestinal microbiome composition combined, and (v) clinical variables and oral microbiome composition combined. In the clinical variables we included age and BMI as additional explanatory variables to control for their effect. Here, we included a total of 62 patients that provided either or both stool and tongue samples. The model trained only on clinical variables was found to predict COVID-19 disease severity with 75.55\% AUC-ROC using leave-one-out cross-validation (Figure $2 \mathrm{~A}$ ) comparable to what have been previously reported ${ }^{1}$. This model determined as significant predictors of COVID-19 disease severity, 10 clinical variables: hypercholesteremia, race (Latino), coronary artery disease, asthma, obesity, hypoxic respiratory stress, tachypnea, days in hospital, thrombosis, and sex (male).

We then performed the same computational analysis but this time assessing the intestinal microbiota (measured in stool, referred as STL) or the oral microbiota (measured in tongue, referred as TNG) as predictors. These models were able to predict COVID-19 disease severity with $92.05 \%$ and $83.79 \%$ AUC-ROC, respectively. These represent an improvement in prediction accuracy of $122 \%$ for intestinal, and $111 \%$ for oral microbiota compared to what is achieved using clinical variables alone (Figure 2A). Furthermore, combining clinical variables and STL or TNG microbiomes abundances improve prediction ability, with the highest AUC-ROC of $96.36 \%$. This analysis suggests that the intestinal and oral microbiotas individually can provide a more accurate and robust biomarker of disease 
medRxiv preprint doi: https://doi.org/10.1101/2021.01.05.20249061; this version posted January 6, 2021. The copyright holder for this preprint (which was not certified by peer review) is the author/funder, who has granted medRxiv a license to display the preprint in perpetuity.

It is made available under a CC-BY-NC-ND 4.0 International license .

severity that may not be quantifiable by other clinical variables assessed during patient triage. Additional metrics on prediction ability of the different models are reported in the Supplementary Table 2.
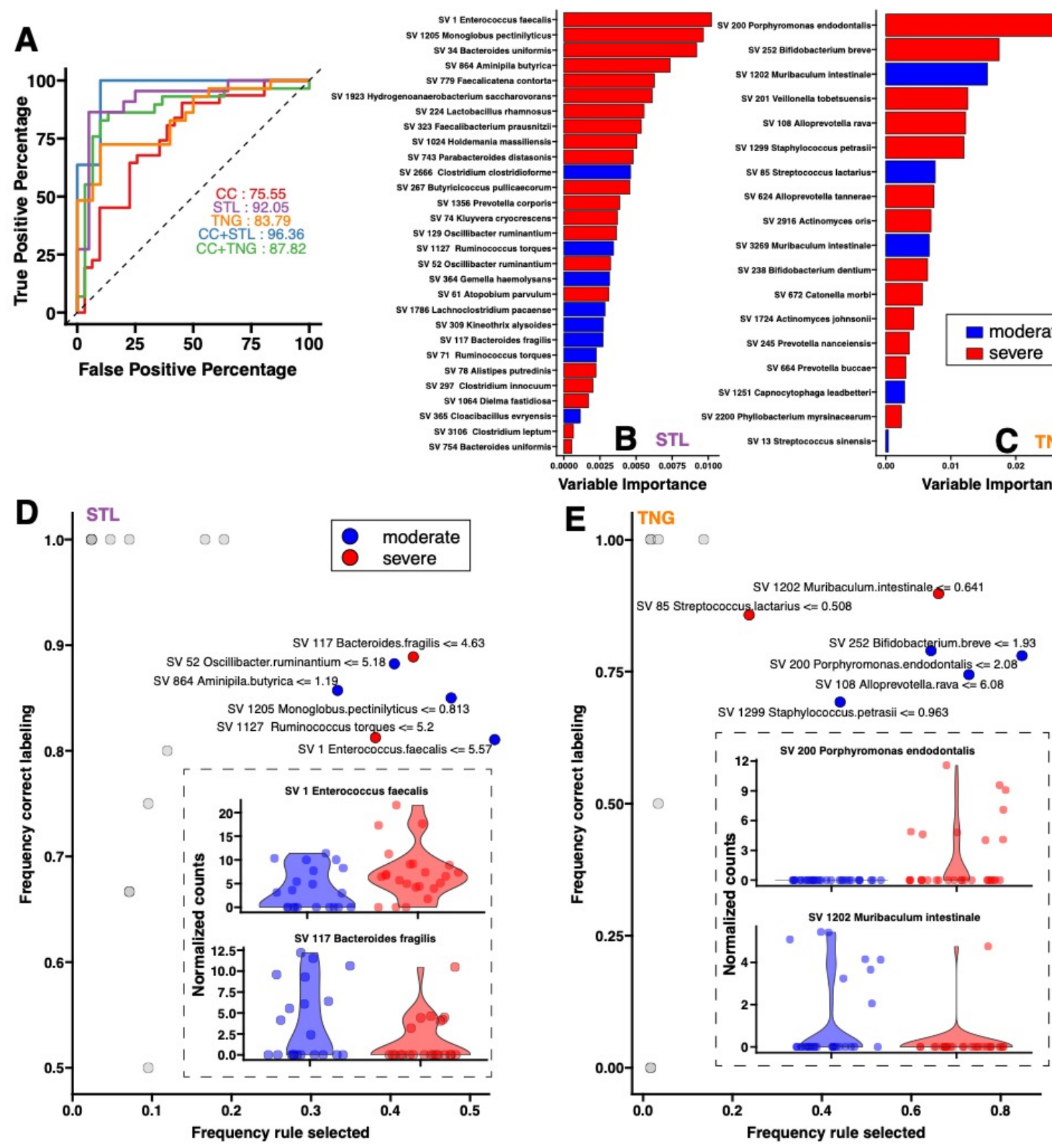

Figure 2. Stool and oral microbiotas predict COVID-19 disease severity with significant greater accuracy compared to clinical variables alone. (A) Receiving Operating Curves (ROCs) for leaveone-out cross-validation evaluating prediction of accuracy of severity for different models. The models accounting for stool microbiome (STL) or oral microbiome (TNG) predict severity with greater accuracy than models trained solely with clinical covariates (CC). Addition of clinical covariates to microbiome 
medRxiv preprint doi: https://doi.org/10.1101/2021.01.05.20249061; this version posted January 6, 2021. The copyright holder for this preprint (which was not certified by peer review) is the author/funder, who has granted medRxiv a license to display the preprint in perpetuity.

It is made available under a CC-BY-NC-ND 4.0 International license .

variables increase predictive ability to $96.36 \%$ AUC. Bacterial species from the microbiome selected by the Random Forest models for STL (B) and TNG (C) ranked according to their importance in classifying COVID-19 disease severity. We ran Local Interpretable Model-agnostic Explanation (LIME) analysis to determine direction of the COVID-19 - microbiota associations. LIME identifies logical rules that best separates between the two outcome groups (moderate $=$ blue, severe $=$ red). For each rule, the frequency of each rule being selected $v s$. the frequency of that rule predicting the true category across all the cross-validation runs are displayed. Rules on Enterococcus faecalis in the STL set (D) and on Porphyromonas endodontalis in the TNG (E) set are found to have primary discriminatory power in classifying COVID-19 disease severity. While the model points to enrichment of these two pathobionts respectively in the intestinal and in the oral mucosa as major predictors of disease severity; conversely, reduction of Bacteroides fragilis and Moribaculum intestinale are also selected as primary COVID-19 disease severity indicators.

\section{Abundance of indicator species is a predictor of COVID-19 disease severity.}

Given the time, expertise, and resources necessary for the analysis and interpretation of microbiota data, we further investigated indicator species of the oral and intestinal microbiota that can be easily cultured in clinical laboratory settings ${ }^{12,13}$ and can be added as a test for risk stratification of COVID-19 patients. In ecological research, indicator species have been defined as those that serve as a surrogate measures of the health or lack thereof of an entire ecosystem ${ }^{14,15}$. We reasoned that indicator species within the microbiota ecosystem could act as surrogate markers of COVID-19 disease severity. Again, after performing feature selection with Boruta, we ran Random Forest Classification using only the Boruta-selected features for every model in Figure 2A. After features ranking based on applied Random Forest Classification-estimated Variable Importance values, we found that the top three bacterial species with the strongest likelihood to predict COVID-19 disease severity from the intestinal microbiome were Bacteroides uniformis (Bacteroides/ Bacteroidia), Enterococcus faecalis (Firmicutes/ Bacilli), and Monoglobus pectinilyticus (Firmicutes/ Clostridia); and from the oral microbiome were Porphyromonas 
medRxiv preprint doi: https://doi.org/10.1101/2021.01.05.20249061; this version posted January 6, 2021. The copyright holder for this preprint (which was not certified by peer review) is the author/funder, who has granted medRxiv a license to display the preprint in perpetuity.

It is made available under a CC-BY-NC-ND 4.0 International license .

endodontalis (Bacteroides/ Bacteroidia), Veillonella tobetsuensis (Firmicutes/ Negavicutes), and Bifidobacterium breve (Actinobacteria/ Actinobacteria. Figure 2B and C).

To determine the direction (positive/negative) of the identified microbial abundances related to COVID-19 severity we then ran Local Interpretable Model-agnostic Explanation (LIME) analysis ${ }^{16}$. LIME trains a local surrogate model that can be used to explain the predictions of a 'black-box' machine learning model such as Random Forest thus providing confidence that the model will perform well on real-world data, crucial for medical decision making. In our context LIME identifies human-interpretable rules on the microbiome that discriminate between patients with moderate or severe COVID-19 symptoms. LIME analyses predicted that reduced abundance in moderately ill patients (and vice versa enrichment in severely ill patients) of the known gastrointestinal pathobiont Enterococcus faecalis and of the oral pathobiont Porphyromonas endodontalis are the top discriminators of COVID-19 disease severity (Figure 2D and E). Conversely, enrichment of Bacteroides fragilis, Bacteroides caccae, and Clostridium clostridioforme in the stool or another Bacteriodetes species: Muribaculum intestinale in the oral cavity are characteristic of individuals with moderate disease. We confirmed that most of the bacteria selected by the machine learning modeling were also different between the two groups by running differential expression analysis for sequence count data with DeSeq2 ${ }^{17}$ (Supplementary Figure 1).

\section{SARS-CoV-2 antibody levels and patient outcomes}

Patients with severe COVID-19 disease have been shown to have a different antibody trajectory compared to those with mild/moderate disease during hospitalization ${ }^{18}$. Although, we only collected one blood sample per patient (at $\sim 6.42 \pm 6.47$ days after hospital admission) we aimed to investigate the relationship between patient microbiota and whether plasma levels of antibodies against the receptor binding domain (RBD) of the SARS-CoV-2 spike protein, specifically: IgA, IgM, and IgG varied depending on disease severity at time of blood collection or among patients who eventually succumbed to the disease vs. those who survived. We did not find any differences in antibody levels by disease severity (Figure 3A); however consistent with previous reports ${ }^{18}$, we observed a significantly lower level of $\lg G$ 
medRxiv preprint doi: https://doi.org/10.1101/2021.01.05.20249061; this version posted January 6, 2021. The copyright holder for this preprint (which was not certified by peer review) is the author/funder, who has granted medRxiv a license to display the preprint in perpetuity.

It is made available under a CC-BY-NC-ND 4.0 International license.

against RBD in patients who eventually died (Figure 3B). High anti-RBD lgG antibody levels measured by ELISA have been shown to correlate with antibodies that block viral entry into host cells as measured neutralizing antibody assays ${ }^{19}$.

We further investigated associations between bacterial abundance and either $\lg A$, $\lg M$ nor $\lg G$ antibody titers (Random Forest classification). We found no bacteria that predicted antibody levels, suggesting these are independent indicators of disease outcome.
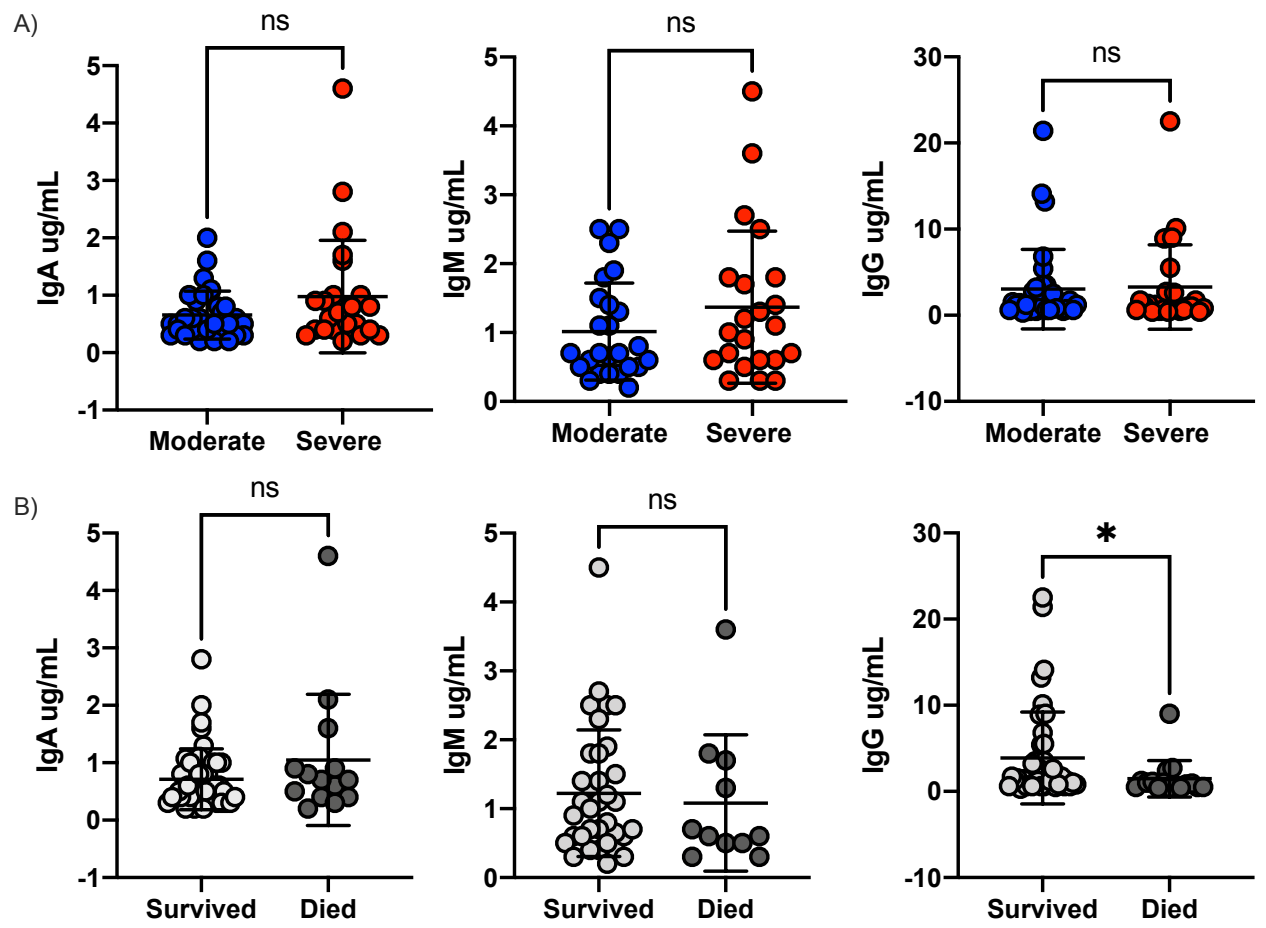

Figure 3. Antibody titers in COVID patients recruited in this study. A total of 54 blood samples were collected from patients that were hospitalized from April to June 2020. A) Antibody titers from patients with moderate (blue) and severe (red) COVID-19 symptoms. B) Antibody titers from patients that survived (light gray) or died (dark grey) to SARS-CoV-2 infection and. *p-value <0.05; Mann-Whitney test. 
medRxiv preprint doi: https://doi.org/10.1101/2021.01.05.20249061; this version posted January 6, 2021. The copyright holder for this preprint (which was not certified by peer review) is the author/funder, who has granted medRxiv a license to display the preprint in perpetuity.

It is made available under a CC-BY-NC-ND 4.0 International license .

\section{DISCUSSION}

In this study, we have demonstrated that COVID-19 disease severity can be predicted by the stool or oral microbiome composition with higher accuracy than traditional clinical scoring methods using a combination of comorbidities and clinical biomarkers alone. Particularly, two pathobionts in the either the oral (Porphyromonas endodontalis) or intestinal (Enterococcus faecalis) microbiota can serve as indicator species to robustly predict the severity of SARS-CoV-2 infections. Our findings are clinically actionable as assessment of Enterococcus faecalis in feces will improve risk stratification of patients, which is highly relevant until this global pandemic is over. Enterococcus faecalis can be cultured from feces representing a cost-effective, rapid, and relatively easy test to implement in clinical settings. As such we urge the medical community that in addition to observable clinical variables, indicator species of the microbiome, specifically Enterococcus faecalis, can serve as robust predictor of COVID-19 severity and to quickly identify patients who are likely to require more supportive care or therapeutic interventions to improve chances of survival.

A hallmark of severe COVID-19 disease is an uncontrolled inflammatory response; specifically, a fulminant and fatal hypercytokinemia that causes an uncontrolled flood of immune cells into the lung ${ }^{20-22}$. In these patients, it's their own uncontrolled inflammatory response, rather than the virus, that causes severe lung injury and multi-organ failures leading to death. Gut microbial dysbiosis has been linked to activation of inflammatory immune networks that perpetuates several chronic diseases ${ }^{23,24}$ (e.g., type 2 diabetes, hyperlipidemia), which are comorbidities associated with COVID-19 disease. Thus, a still unanswered question is the contribution of the microbiome in the immune response against SASR-CoV-2 infection.

A recent study has shown that SARS-CoV-2 infection triggers aberrant phenotypes of FoxP3+ T regulatory cells $\left(\right.$ Treg ${ }^{25}$, critical to immune homeostasis (reviewed ${ }^{26,27}$ ). We and others have demonstrated the microbiota-dependent development and activation of Treg and their role in controlling exacerbated inflammatory responses ${ }^{4,28-36}$. Thus, further studies with longitudinal sampling combined 
medRxiv preprint doi: https://doi.org/10.1101/2021.01.05.20249061; this version posted January 6, 2021. The copyright holder for this preprint (which was not certified by peer review) is the author/funder, who has granted medRxiv a license to display the preprint in perpetuity.

It is made available under a CC-BY-NC-ND 4.0 International license .

with analysis of Treg markers are needed to better understand how the dysbiosis in SARS-CoV-2 infected patients, and specifically the enrichment of the pathobionts we observed in this cohort, can contribute to COVID-19 disease severity via alteration of the Treg development.

\section{ACKNOWLEDGMENTS}

All faculty members of the Microbiology and Physiological Systems Department and the EH\& S at UMASS for insightful advice on sample containment. We are grateful for all the patients that participated in the study. We thank Katherine Fitzgerald for providing access to the BSL2+ laboratories to safely process all the samples. The Center for Microbiome Center, AM, GF, CF received funding to execute this study by the COVID-19/Pandemic Research Fund at UMass Medical School. Funding sources for AM, GF, CF were also provided by MassCPR Evergrande Award.

\section{METHODS}

Participant recruitment: We enrolled SARS-CoV-2 PCR positive patients with moderate (requiring $<4 \mathrm{~L}$ of oxygen) or severe (requiring $>4 \mathrm{~L}$ of oxygen) symptoms hospitalized at the University of Massachusetts Medical Center and UMASS Memorial Hospital from April 27 to June 10, 2020. This cohort was recruited under the COVID-COPE IRB protocol (docket \# H00020145). The Institutional Review Board at the University of Massachusetts Medical School approved this study. Informed consent was obtained from all study participants or their health care proxy using RedCap digital signatures to reduce the potential for patient-staff transmission.

Sample collection: All samples were collected by the doctor or nurse caring for the patient during standard of care rounds using all the necessary precautions. Stool samples were collected with a scoop from a paper stool catcher or directly from the ostomy bags into a sterile tube (Cat \# 58-EZSAMPLER, ALPCO, NH, USA). Oral swabs were obtained using the OMNIgene•ORAL (DNAGenotek ${ }^{\mathrm{TM}}$, Canada) following the manufacturer instructions. Briefly, the tongue was swabbed for 30 seconds and then the swab was inserted into a tube with a DNA/RNA stabilizer buffer. For antibody assays, blood was 
medRxiv preprint doi: https://doi.org/10.1101/2021.01.05.20249061; this version posted January 6, 2021. The copyright holder for this preprint (which was not certified by peer review) is the author/funder, who has granted medRxiv a license to display the preprint in perpetuity.

It is made available under a CC-BY-NC-ND 4.0 International license .

collected in EDTA tubes (5 mL. BD Vacutainer® tubes, Becton Dickinson, USA) using sterile technique and blood borne pathogen precautions enhanced for COVID-19 patients. Plasma was separated from peripheral blood cell pellet by centrifugation, 10 minutes, room temperature and aliquots stored at $-20^{\circ} \mathrm{C}$ until thawed for ELISA testing.

Clinical data: All the clinical data was obtained retrospectively by reviewing medical records of each participant.

DNA and RNA isolation: Prior to isolation, SARS-CoV-2 was inactivated in all samples by heat at $65-70$ ${ }^{\circ} \mathrm{C}$ for one hour as done elsewhere ${ }^{37,38}$. After viral deactivation, nucleic acid isolation for stool and oral samples was performed using the ZymoBIOMICS DNA/RNA Miniprep Kit (Cat \# D7003/D7003T, Zymo Research, CA, USA) following the manufacturer recommendations for parallel isolation of DNA and RNA. Oral samples were first treated with the addition of 5ul Proteinase K (Cat \# P8107S, New England Biolabs, MA, USA) and incubated for 2 hours at $50^{\circ} \mathrm{C} .250 \mathrm{ul}^{\circ}$ of the treated sample was used for extraction. Extraction of total RNA from blood samples was performed using the Tempus ${ }^{\mathrm{TM}}$ Spin RNA isolation kit (Cat \# 4380204, Applied Biosystems, USA) following manufactures instructions.

\section{Microbiome profiling:}

The $16 S$ rRNA gene was sequenced following methods previously described ${ }^{39}$ using the $341 \mathrm{~F}$ and 806R universal primers to amplify the V3-V4 region. The 300nt paired-end sequences were generated on the Illumina MiSeq platform. Replicate reactions were performed for each sample and the read data was combined in analysis. Forward and reverse 16S MiSeq-generated amplicon sequencing reads were dereplicated and sequences were inferred using dada2 ${ }^{40}$. Potentially chimeric sequences were removed using consensus-based methods. Taxonomic assignments were made using BLASTN against the NCBI refseq rna database. These files were imported into $\mathrm{R}$ and merged with a metadata file into a single Phyloseq object. 
medRxiv preprint doi: https://doi.org/10.1101/2021.01.05.20249061; this version posted January 6, 2021. The copyright holder for this preprint (which was not certified by peer review) is the author/funder, who has granted medRxiv a license to display the preprint in perpetuity.

It is made available under a CC-BY-NC-ND 4.0 International license .

\section{Mathematical modeling:}

Machine learning analysis to predict outcome from microbiome and clinical covariates: We run random forest classification (RFC) to identify stool, oral bacteria and clinical covariates that are predictive of clinical outcome SARS-CoV-2 disease fatality and severity. Our RFC pipeline consists in a first step of feature selection in where the wrapper Boruta ${ }^{41}$ is used to determine a subset of covariates that is predictive of the outcome, and a second step in where RFC is run using only the Boruta-selected subset. To estimate the accuracy in predicting clinical outcome we used leave-one-out cross-validation scheme and corresponding Area Under the Curve (AUC). AUC values were used to compare different models in terms of prediction accuracy. To interpret the results from the RFC analysis, the RFC models were input into Local Interpretable Model-agnostic Explanation (LIME) toolbox ${ }^{42}$. LIME trains a local surrogate model that explains the predictions of black-box machine learning model such as Random Forest. In our context LIME identifies human-interpretable logical rules on the microbiome that discriminate between patients with different outcomes (e.g., abundance of bacterium $X$ less that normalized count $K$ is characteristic of Severity Moderate). The LIME output was used to determine the prevalence of a rule (e.g., in how many cross-validations a rule was selected) and the number of times it contributes to predicting the correct label. This computational scheme was used to predict SARS-CoV-2 disease fatality and severity (binary variables). The clinical covariates corresponding to categorical variables were onehot-encoded. For microbial abundances we used the Amplicon Sequence Variant (ASV) counts normalized using DeSeq2 ${ }^{43}$.

Differential analysis to confirm microbiota-outcome associations: To confirm the associations between stool and oral bacteria and clinical outcome we run Differential expression analysis for Sequence count data in DeSeq2 as done previously ${ }^{44}$. Specifically, we run the model Counts $\sim$ Phenotype + CC (where CC stands for the main clinical covariates selected by the only CC model). ASVs with BenjaminHochberg adjusted $\mathrm{p}$ value less than 0.05 for the Phenotype variable were considered differential. 
medRxiv preprint doi: https://doi.org/10.1101/2021.01.05.20249061; this version posted January 6, 2021. The copyright holder for this preprint (which was not certified by peer review) is the author/funder, who has granted medRxiv a license to display the preprint in perpetuity.

It is made available under a CC-BY-NC-ND 4.0 International license.

\section{Antibody ELISA:}

Antibodies against the receptor binding domain (RBD) of the SARS-CoV-2 spike protein were measured by ELISA following published methods ${ }^{45}$. In brief, IgG, IgA and IgM antibodies against the RBD recombinant protein (gifted from MassBiologics) was used at $0.5 \mu \mathrm{g} / \mathrm{mL}$ and incubated with plasma at a 1:100 and 1:1000 dilution. Absorbance was measured at $450 \mathrm{~nm}$ and $570 \mathrm{~nm}$ on the SpectraMax iD5 ELISA plate reader (Molecular Devices) using SoftMax Pro software (version 7.1, Molecular Devices). For the positive antibody control, CR3022 was diluted from a concentration of $2.5 \mu \mathrm{g} / \mathrm{ml}$ in dilution buffer to 12 two-fold serial dilutions to generate the standard control curve. The $570 \mathrm{~nm}$ OD was subtracted from the $450 \mathrm{~nm}$ OD for the final OD value. Antibody levels were used as a continuous variable in the analysis.

\section{Statistical analysis:}

Fisher T-test, Chi-square, and Mann-Whitney tests were used to evaluate differences in demographics and antibiotic use among patients with moderate vs. severe COVID-19 disease. A non-parametric MannWhitney U-test was also used to evaluate differences in antibody titer in serum by disease severity or clinical outcome. 
medRxiv preprint doi: https://doi.org/10.1101/2021.01.05.20249061; this version posted January 6, 2021. The copyright holder for this preprint (which was not certified by peer review) is the author/funder, who has granted medRxiv a license to display the preprint in perpetuity.

It is made available under a CC-BY-NC-ND 4.0 International license .

\section{REFERENCES:}

1 Knight, S. R. et al. Risk stratification of patients admitted to hospital with covid-19 using the ISARIC WHO Clinical Characterisation Protocol: development and validation of the 4C Mortality Score. BMJ 370, m3339, doi:10.1136/bmj.m3339 (2020).

2 Villapol, S. Gastrointestinal symptoms associated with COVID-19: impact on the gut microbiome. Transl Res 226, 57-69, doi:10.1016/j.trsl.2020.08.004 (2020).

3 Zuo, T. et al. Alterations in Gut Microbiota of Patients With COVID-19 During Time of Hospitalization. Gastroenterology 159, 944-955 e948, doi:10.1053/j.gastro.2020.05.048 (2020).

4 Stein, R. R. et al. Computer-guided design of optimal microbial consortia for immune system modulation. Elife 7, doi:10.7554/eLife.30916 (2018).

5 Bucci, V. et al. MDSINE: Microbial Dynamical Systems INference Engine for microbiome timeseries analyses. Genome biology 17, 121, doi:10.1186/s13059-016-0980-6 (2016).

6 Bucci, V. \& Xavier, J. B. Towards predictive models of the human gut microbiome. J Mol Biol 426, 3907-3916, doi:10.1016/j.jmb.2014.03.017 (2014).

$7 \quad$ Haran, J. P. et al. Alzheimer's Disease Microbiome Is Associated with Dysregulation of the AntiInflammatory P-Glycoprotein Pathway. MBio 10, doi:10.1128/mBio.00632-19 (2019).

8 Groves, H. T., Higham, S. L., Moffatt, M. F., Cox, M. J. \& Tregoning, J. S. Respiratory Viral Infection Alters the Gut Microbiota by Inducing Inappetence. mBio 11, doi:10.1128/mBio.0323619 (2020).

9 Hanada, S., Pirzadeh, M., Carver, K. Y. \& Deng, J. C. Respiratory Viral Infection-Induced Microbiome Alterations and Secondary Bacterial Pneumonia. Front Immunol 9, 2640, doi:10.3389/fimmu.2018.02640 (2018).

10 Wasimuddin et al. Adenovirus infection is associated with altered gut microbial communities in a non-human primate. Sci Rep 9, 13410, doi:10.1038/s41598-019-49829-z (2019).

11 Zuo, T. et al. Depicting SARS-CoV-2 faecal viral activity in association with gut microbiota composition in patients with COVID-19. Gut, doi:10.1136/gutjnl-2020-322294 (2020). 
medRxiv preprint doi: https://doi.org/10.1101/2021.01.05.20249061; this version posted January 6, 2021. The copyright holder for this preprint (which was not certified by peer review) is the author/funder, who has granted medRxiv a license to display the preprint in perpetuity.

It is made available under a CC-BY-NC-ND 4.0 International license .

12 Knudtson, L. M. \& Hartman, P. A. Routine procedures for isolation and identification of enterococci and fecal streptococci. Appl Environ Microbiol 58, 3027-3031, doi:10.1128/AEM.58.9.3027-3031.1992 (1992).

13 Ruoff, K. L., de la Maza, L., Murtagh, M. J., Spargo, J. D. \& Ferraro, M. J. Species identities of enterococci isolated from clinical specimens. J Clin Microbiol 28, 435-437, doi:10.1128/JCM.28.3.435-437.1990 (1990).

14 Landres PB, V. J., Thomas JW. Ecological uses of vertebrate indicator species: a critique. Conserv Biol 2, 316-328 (1988).

15 Diekmann, M. Species indicator values as an important tool in applied plant ecology - a review. Basic and Applied Ecology 4, 493-506 (2003).

16 Ahern, P. P., Faith, J. J. \& Gordon, J. I. Mining the human gut microbiota for effector strains that shape the immune system. Immunity 40, 815-823, doi:10.1016/j.immuni.2014.05.012 (2014).

17 Anders, S. \& Huber, W. Differential expression analysis for sequence count data. Genome Biol 11, R106, doi:10.1186/gb-2010-11-10-r106 (2010).

18 Li, K. et al. Dynamic changes in anti-SARS-CoV-2 antibodies during SARS-CoV-2 infection and recovery from COVID-19. Nat Commun 11, 6044, doi:10.1038/s41467-020-19943-y (2020).

19 Premkumar, L. et al. The receptor binding domain of the viral spike protein is an immunodominant and highly specific target of antibodies in SARS-CoV-2 patients. Sci Immunol 5, doi:10.1126/sciimmunol.abc8413 (2020).

20 Parra-Medina, R., Herrera, S. \& Mejia, J. Comments to: A systematic review of pathological findings in COVID-19: a pathophysiological timeline and possible mechanisms of disease progression. Mod Pathol, doi:10.1038/s41379-020-0631-z (2020).

21 Mehta, P. et al. COVID-19: consider cytokine storm syndromes and immunosuppression. Lancet 395, 1033-1034, doi:10.1016/S0140-6736(20)30628-0 (2020).

22 Chen, G. et al. Clinical and immunological features of severe and moderate coronavirus disease 2019. J Clin Invest 130, 2620-2629, doi:10.1172/JCI137244 (2020). 
medRxiv preprint doi: https://doi.org/10.1101/2021.01.05.20249061; this version posted January 6, 2021. The copyright holder for this preprint (which was not certified by peer review) is the author/funder, who has granted medRxiv a license to display the preprint in perpetuity. It is made available under a CC-BY-NC-ND 4.0 International license .

Hand, T. W., Vujkovic-Cvijin, I., Ridaura, V. K. \& Belkaid, Y. Linking the Microbiota, Chronic Disease, and the Immune System. Trends Endocrinol Metab 27, 831-843, doi:10.1016/j.tem.2016.08.003 (2016).

24 Zheng, D., Liwinski, T. \& Elinav, E. Interaction between microbiota and immunity in health and disease. Cell Res 30, 492-506, doi:10.1038/s41422-020-0332-7 (2020). Yang, Angela Magnuson, Zachary Manickas-Hill, Alicja Piechocka-Trocha, Daniel P. Worrall, Kathryn E. Hall, Musie Ghebremichael, Bruce D. Walker, Jonathan Z. Li, Xu G. Yu, MGH COVID19 Collection and Processing Team, Diane Mathis, Christophe Benoist. Profound Treg perturbations correlate with COVID-19 severity (bioRxiv, 2020).

Smigiel, K. S., Srivastava, S., Stolley, J. M. \& Campbell, D. J. Regulatory T-cell homeostasis: steady-state maintenance and modulation during inflammation. Immunol Rev 259, 40-59, doi:10.1111/imr.12170 (2014).

27 Sakaguchi, S., Yamaguchi, T., Nomura, T. \& Ono, M. Regulatory T cells and immune tolerance. Cell 133, 775-787, doi:10.1016/j.cell.2008.05.009 (2008).

28 Atarashi, K. et al. Induction of colonic regulatory T cells by indigenous Clostridium species. Science 331, 337-341, doi:10.1126/science.1198469 (2011).

29 Pandiyan, P. et al. Microbiome Dependent Regulation of Tregs and Th17 Cells in Mucosa. Front Immunol 10, 426, doi:10.3389/fimmu.2019.00426 (2019).

30 Tanoue, T., Atarashi, K. \& Honda, K. Development and maintenance of intestinal regulatory T cells. Nat Rev Immunol 16, 295-309, doi:10.1038/nri.2016.36 (2016).

$31 \mathrm{Li}, \mathrm{Y}$. N. et al. Effect of oral feeding with Clostridium leptum on regulatory T-cell responses and allergic airway inflammation in mice. Ann Allergy Asthma Immunol 109, 201-207, doi:10.1016/j.anai.2012.06.017 (2012).

32 Campbell, C. et al. Extrathymically Generated Regulatory T Cells Establish a Niche for Intestinal Border-Dwelling Bacteria and Affect Physiologic Metabolite Balance. Immunity 48, 1245-1257 e1249, doi:10.1016/j.immuni.2018.04.013 (2018). 
medRxiv preprint doi: https://doi.org/10.1101/2021.01.05.20249061; this version posted January 6, 2021. The copyright holder for this preprint (which was not certified by peer review) is the author/funder, who has granted medRxiv a license to display the preprint in perpetuity. It is made available under a CC-BY-NC-ND 4.0 International license .

Atarashi, K. et al. Th17 Cell Induction by Adhesion of Microbes to Intestinal Epithelial Cells. Cell 163, 367-380, doi:10.1016/j.cell.2015.08.058 (2015).

Furusawa, Y. et al. Commensal microbe-derived butyrate induces the differentiation of colonic regulatory T cells. Nature 504, 446-450, doi:10.1038/nature12721 (2013).

Atarashi, K. et al. Treg induction by a rationally selected mixture of Clostridia strains from the human microbiota. Nature 500, 232-236, doi:10.1038/nature12331 (2013).

Round, J. L. \& Mazmanian, S. K. Inducible Foxp3+ regulatory T-cell development by a commensal bacterium of the intestinal microbiota. Proceedings of the National Academy of Sciences of the United States of America 107, 12204-12209, doi:10.1073/pnas.0909122107 (2010).

Rabenau, H. F. et al. Stability and inactivation of SARS coronavirus. Med Microbiol Immunol 194, 1-6, doi:10.1007/s00430-004-0219-0 (2005).

Erickson TB; Chai PR; Thompson J; Alm EJ, W. F. X. A. Z. J. G. X. L. W. K. K. H. W. M. M. G. N. E. N. D. C. M. K. SARS-CoV-2 titers in wastewater are higher than expected from clinically confirmed cases (MedRix, 2020).

39 Kozich, J. J., Westcott, S. L., Baxter, N. T., Highlander, S. K. \& Schloss, P. D. Development of a dual-index sequencing strategy and curation pipeline for analyzing amplicon sequence data on the MiSeq Illumina sequencing platform. Appl Environ Microbiol 79, 5112-5120, doi:10.1128/AEM.01043-13 (2013).

40 Callahan, B. J. et al. DADA2: High-resolution sample inference from Illumina amplicon data. Nat Methods 13, 581-583, doi:10.1038/nmeth.3869 (2016).

41 Kursa, M. B. a. R., Witold R. Feature Selection with the Boruta Package. Journal of Statistical Software, Foundation for Open Access Statistics 36 (2010).

Rosal, M. C. et al. Facilitating dietary change: the patient-centered counseling model. Journal of the American Dietetic Association 101, 332-341, doi:10.1016/S0002-8223(01)00086-4 (2001). seq data with DESeq2. Genome Biol 15, 550, doi:10.1186/s13059-014-0550-8 (2014). 
medRxiv preprint doi: https://doi.org/10.1101/2021.01.05.20249061; this version posted January 6, 2021. The copyright holder for this preprint (which was not certified by peer review) is the author/funder, who has granted medRxiv a license to display the preprint in perpetuity. It is made available under a CC-BY-NC-ND 4.0 International license.

44 Wipperman, M. F. et al. Antibiotic treatment for Tuberculosis induces a profound dysbiosis of the microbiome that persists long after therapy is completed. Sci Rep 7, 10767, doi:10.1038/s41598017-10346-6 (2017).

45 Roy, V. et al. SARS-CoV-2-specific ELISA development. J Immunol Methods 484-485, 112832, doi:10.1016/j.jim.2020.112832 (2020). 
medRxiv preprint doi: https://doi.org/10.1101/2021.01.05.20249061; this version posted January 6, 2021. The copyright holder for this preprint (which was not certified by peer review) is the author/funder, who has granted medRxiv a license to display the preprint in perpetuity.

It is made available under a CC-BY-NC-ND 4.0 International license .

Supplementary Table 1. Clinical variables included in the models obtained by review of medical records.

\begin{tabular}{|c|c|c|c|}
\hline Clinical variables included in the models & $\begin{array}{c}\text { Moderate } \\
(n=32)\end{array}$ & $\begin{array}{l}\text { Severe } \\
(n=31)\end{array}$ & $\begin{array}{l}\text { Mann Whitney } \\
\text { tests ( } p \text { value) }\end{array}$ \\
\hline \multicolumn{4}{|l|}{ Symptoms } \\
\hline Abdominal pain & 1 & 1 & $>0.999999$ \\
\hline Chest pain & 2 & 3 & 0.671867 \\
\hline Chills & 5 & 6 & 0.74996 \\
\hline Cough & 12 & 12 & $>0.999999$ \\
\hline Diarrhea & 3 & 4 & 0.707846 \\
\hline Difficulty breathing & 16 & 22 & 0.12349 \\
\hline Dizziness & 1 & 0 & $>0.999999$ \\
\hline Dyspnea & 14 & 19 & 0.210129 \\
\hline Fever & 11 & 17 & 0.131294 \\
\hline Hemoptysis & 0 & 1 & 0.492063 \\
\hline Hypotension & 4 & 2 & 0.671867 \\
\hline Hypoxic respiratory distress & 18 & 25 & 0.057677 \\
\hline Shortness of breath & 16 & 21 & 0.202826 \\
\hline Sore throat & 1 & 0 & $>0.999999$ \\
\hline Tachycardia & 9 & 11 & 0.595035 \\
\hline Tachypnea & 11 & 17 & 0.131294 \\
\hline Vomiting & 4 & 2 & 0.671867 \\
\hline Anemia & 3 & 5 & 0.474123 \\
\hline \multicolumn{4}{|l|}{ Co-morbidities } \\
\hline Asthma & 7 & 2 & 0.147716 \\
\hline Bradycardia & 2 & 0 & 0.492063 \\
\hline Cardiomyopathy & 3 & 2 & $>0.999999$ \\
\hline Cancer & 6 & 8 & 0.556127 \\
\hline Cerebellar atrophy & 0 & 0 & $>0.999999$ \\
\hline Cerebral palsy & 1 & 0 & $>0.999999$ \\
\hline Chronic fibrillation & 6 & 8 & 0.556127 \\
\hline Chronic anticoagulation & 3 & 6 & 0.302018 \\
\hline Heart failure & 8 & 12 & 0.286909 \\
\hline Kidney disease & 7 & 8 & 0.773534 \\
\hline Chronic respiratory failure & 2 & 7 & 0.081587 \\
\hline Thrombosis & 4 & 1 & 0.354671 \\
\hline Cirrhosis & 1 & 1 & $>0.999999$ \\
\hline Congestive heart failure & 7 & 12 & 0.176864 \\
\hline COPD & 3 & 7 & 0.183638 \\
\hline Coronary artery disease & 2 & 8 & 0.043318 \\
\hline Emphysema & 0 & 2 & 0.238095 \\
\hline End stage renal disease & 2 & 5 & 0.248622 \\
\hline
\end{tabular}


medRxiv preprint doi: https://doi.org/10.1101/2021.01.05.20249061; this version posted January 6, 2021. The copyright holder for this preprint (which was not certified by peer review) is the author/funder, who has granted medRxiv a license to display the preprint in perpetuity. It is made available under a CC-BY-NC-ND 4.0 International license.

\begin{tabular}{|c|c|c|c|}
\hline Epilepsy & 2 & 4 & 0.425766 \\
\hline Goodpasture syndrome & 1 & 0 & $>0.999999$ \\
\hline Heart attack & 0 & 1 & 0.492063 \\
\hline Heart failure & 8 & 13 & 0.187691 \\
\hline Hepatic encephalopathy & 1 & 0 & $>0.999999$ \\
\hline History (hx) adenocarcinoma & 1 & 3 & 0.354671 \\
\hline History (hx) aortic aneurysm & 1 & 0 & $>0.999999$ \\
\hline History (hx) cancer & 6 & 8 & 0.556127 \\
\hline Hypercholesteremia & 1 & 11 & 0.001153 \\
\hline Hyperglycemia & 13 & 15 & 0.61593 \\
\hline Hyperlipidemia & 16 & 13 & 0.620886 \\
\hline Hypertension & 23 & 26 & 0.36492 \\
\hline Hypotension & 0 & 1 & 0.492063 \\
\hline Interstitial lung disease & 0 & 1 & 0.492063 \\
\hline Lymphoma & 1 & 0 & $>0.999999$ \\
\hline Multiple myeloma & 1 & 1 & $>0.999999$ \\
\hline Nephrectomy & 0 & 1 & 0.492063 \\
\hline Parkinson's & 0 & 1 & 0.492063 \\
\hline Renal disease & 7 & 8 & 0.773534 \\
\hline Renal failure & 2 & 5 & 0.256519 \\
\hline Stage 3 chronic kidney disease & 4 & 4 & $>0.999999$ \\
\hline Stage 4 adenocarcinoma & 1 & 1 & $>0.999999$ \\
\hline Stage 5 end stage renal disease & 2 & 5 & 0.256519 \\
\hline Type 1 diabetes & 0 & 1 & 0.492063 \\
\hline Type 2 diabetes & 13 & 15 & 0.61593 \\
\hline
\end{tabular}


medRxiv preprint doi: https://doi.org/10.1101/2021.01.05.20249061; this version posted January 6, 2021. The copyright holder for this preprint (which was not certified by peer review) is the author/funder, who has granted medRxiv a license to display the preprint in perpetuity. It is made available under a CC-BY-NC-ND 4.0 International license.

Supplementary Table 2. Performance metrics of different Random Forest Classification Models predicting COVID-19 severity (moderate vs. severe). SEN=Sensitivity, SPEC=Specificity, PPV=Positive Predicted Values, NPV=Negative Predicted Values, PREC=Precision, REC=Recall, F1=F1 Score.

\begin{tabular}{l|lllllll}
\multicolumn{1}{c}{ MODEL } & SEN & SPEC & PPV & NPV & PREC & REC & F1 \\
\hline CC & 0.68 & 0.68 & 0.68 & 0.68 & 0.68 & 0.68 & 0.68 \\
STL & 0.86 & 0.85 & 0.86 & 0.85 & 0.86 & 0.86 & 0.86 \\
TNG & 0.72 & 0.87 & 0.84 & 0.76 & 0.84 & 0.72 & 0.78 \\
CC + STL & 1.00 & 0.80 & 0.85 & 1.00 & 0.85 & 1.00 & 0.92 \\
CC + TNG & 0.76 & 0.90 & 0.88 & 0.79 & 0.88 & 0.76 & 0.81
\end{tabular}


medRxiv preprint doi: https://doi.org/10.1101/2021.01.05.20249061; this version posted January 6, 2021. The copyright holder for this preprint (which was not certified by peer review) is the author/funder, who has granted medRxiv a license to display the preprint in perpetuity.

It is made available under a CC-BY-NC-ND 4.0 International license .

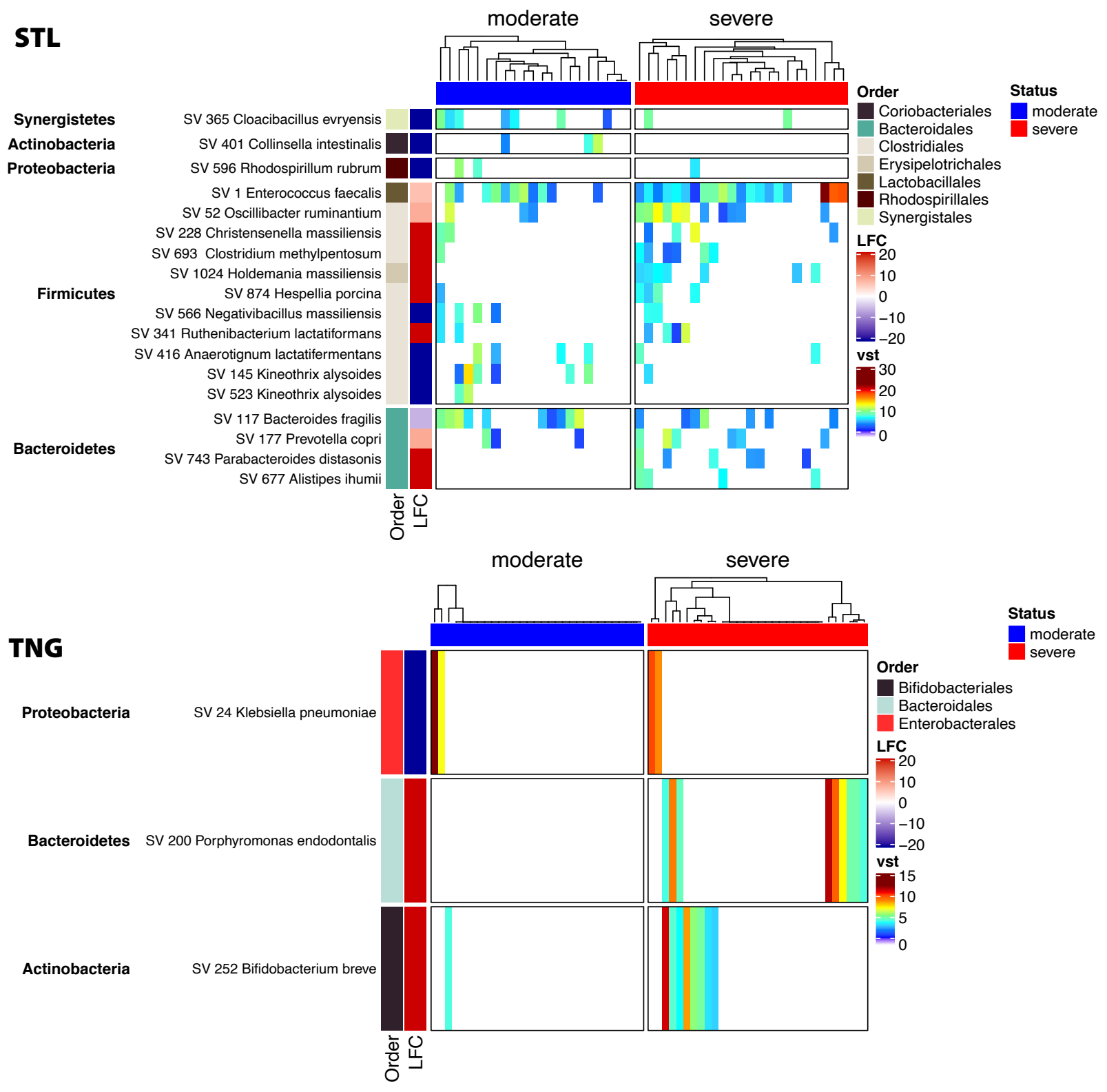

Supplementary Figure 1: Differential Analysis results from DeSeq2. DeSeq2 was used to fit the model Counts $\sim$ Severity for the stool $(S T L)$ or oral (TNG) microbiomes. Heatmap display Amplicon Sequence Variants (ASVs) with significant $p$ value $(\mathrm{BH}$ corrected $p$ value $<0.05)$. 